\title{
POPE JOHN PAUL II'S CONCEPT OF THE INDIRECT EMPLOYER AS EXEMPLIFIED BY TRANSNATIONAL CORPORATIONS*
}

\begin{abstract}
The term "indirect employer" when used in labour law literature usually refers to the usage of work performed by persons formally employed by a third party. In such a situation, employee seems to have the direct (formal) employer and the indirect one who appropriates the results of the work done without entering into an employment relationship. Pope John Paul II in the encyclical Laborem Exercens uses the notion of the indirect employer in a somewhat different meaning. The Pope refers rather to the sphere of politics and the ability to shape the statutory labour law or the actual working (living) standards for the entire society.

The article explains the concept of the indirect employer as it was used in the encyclical and indicates the ideas that are behind it. The article also attempts to show the usefulness of the John Paul II's concept of the indirect employer in considering issues related to the transnational corporations and labour law.
\end{abstract}

Słowa kluczowe: pracodawca pośredni, przedsiębiorstwa wielonarodowe, Jan Paweł II

Keywords: indirect employer, multinational enterprises, John Paul II

ASJC: 3308, JEL: K31

\section{Introduction}

One of the challenges that labour law has been facing for decades is the growth of the influence of transnational corporations. The first wave of academic interest in this topic arose in the 1970s, the second took place in the 1990s in connection with the geopolitical changes of that time, giving globalization a new impetus. The interest of

* The article is a developed and completed version of the conference paper Korporacje transnarodowe jako pracodawca pośredni [in:] A. Reda-Ciszewska, M. Włodarczyk (red.), Wartości i interesy a prawo pracy. Wokót Encykliki Laborem Exercens Jana Pawła II, Łódź 2014. 
labour law scholars in the subject of multinational enterprises is still very strong. Surely, the EU with its regulations on community-scale undertakings contributes to that. Some bottom up processes also play an important and inspiring role (it is enough to mention the corporate codes of conduct, TCAs and IFAs).

The range of labour law ideas relating to the phenomenon of transnational corporations can be broadened by the notion of the indirect employer as used by Pope John Paul II in his Laborem Exercens encyclical (1981).

Laborem Exercens encyclical, as a document on Catholic social teaching, is neither an economic, nor sociological and nor legal study. Social teaching of the Church is a part of theology and, in particular, moral theology. As written in Sollicitudo Rei Socialis, the Church's social doctrine is "the accurate formulation of the results of a careful reflection on the complex realities of human existence, in society and in the international order, in the light of faith and of the Church's tradition" (John Paul II, 1987, sec. 41). Catholic social teaching addresses social problems, assuming that "the theological dimension is needed both for interpreting and solving present-day problems in human society" (John Paul II 1991, sec. 55; see also Lower 2007, p. 115).

\section{The notion of the indirect employer in Laborem Exercens and labour law studies}

Naturally, Catholic social teaching documents refer to knowledge from many scientific fields. This results from the fact that moral teaching in social matters is based on the knowledge of the social reality which is the subject of many scientific disciplines. In the case of Laborem Exercens and the notion of the indirect employer the situation is slightly different. The Pope creates here his own concept that can broaden the horizons of e.g. the labour law doctrine. In Laborem Exercens, the Pope uses the notion of indirect employer to describe "many different factors, other than the direct employer, that exercise a determining influence on both the shaping of the work contract and, consequently, of just or unjust relationships in the field of human labour" (John Paul II 1981, sec. 17). Pope John Paul II's concept of the indirect employer "includes both persons and institutions of various kinds, and also collective labour contracts and the principles of conduct which are laid down by these persons and institutions and which determine the whole socioeconomic system or are its result" (John Paul II 1981, sec. 17). Therefore, the notion of the indirect employer covers various ontological meanings. Indeed, it includes states, trade unions, collective wage agreements and socioeconomic principles. By this broad definition of indirect employer the Pope shows that many circumstances and actors contribute to the existing working (or even living) conditions. The Pope's approach should be considered in the context of the subsidiarity principle, which exposes interactions between factors of different levels (Lower 2007, p. 146-147) as well as in the light of the principle of solidarity that is central to Catholic social teaching (McMorran Sulentic 2006, p. 533-534). Furthermore, the broad definition 
seems to convey the idea that moral obligations are more far-reaching than legal responsibilities (Lower 2007, p. 149).

While seemingly intuitive, the term "indirect employer", is not very often found in labour law literature. If it appears, it does not have the meaning attributed to it by Pope John Paul II, and usually refers to the usage of work performed by persons formally employed by a third party. In such a situation, the employee seems to have the direct (formal) employer and the indirect one who appropriates the results of work without entering into an employment relationship. Such an indirect employer can be exemplified by the user undertaking (in relation to the employees of temporary work agencies), the general contractor (in relation to the employees of its subcontractors), the retailer (in relation to the employees of the "links" in its supply chain), ${ }^{1}$ or the parent company in relation to the employees of its subsidiaries. The term indirect employer in a broader meaning appears sometimes with reference to the state (at the time when Poland was a "social democracy", the state seemed to be the basic denotation of this term; Zieliński 1986, p. 243; Wratny 1994, p. 89, 91), or even to consumers (Kelley 1908, p. 109). It is also present in the US jurisprudence relating both to collective and individual labour relations (it is related there to the doctrine of joint employers and joint employment, see e.g. Garcia 2016, especially p. 753-758, 764; with regard to the liability for discrimination: Johnson 2005, especially p. 577-578).

In fact, the usefulness of the Pope's very broad concept of indirect employer for legal studies has been questioned. Walerian Sanetra, an influential Polish scholar working on labour law, made an accurate observation that while the Pope's concept of indirect employer might be valuable for ethical, philosophical and political-science considerations, it is difficult to accept it as a useful tool for the exploration and implementation of labour law. Sanetra goes on to argue that the ambiguity and imprecise, unclear meaning of this term make it unfit for legal dogmatic considerations, which require strictness and pinpoint accuracy (Sanetra 1989, p. 19; Wagner 1990, p. 91). Non-legal literature too, assessed the distinctions made by the Pope as "unusual" (Williams 1982, p. 477).

Nevertheless, the critical assessment of the usefulness of the John Paul II's concept of indirect employer for legal considerations does not, as argued by Sanetra himself, reduce the general value of this idea. It is important to bear in mind that the papal concept of indirect employer is not a legal one and, consequently, it does not strive for scientific precision (Wagner 1990, p. 89). At the same time, it seems that the classic methods of precise legal analysis are not suitable for exploring new, general and interdisciplinary issues such as the issue of transnational corporations. Thus, making reference in that regard to the Pope's notion of the indirect employer can prove instructive.

${ }^{1}$ See e.g. Davidov 2015, especially p. 11 - the author uses here the term indirect employment to describe activities of the temporary employment agencies, franchise networks, subcontracting and supply chains. See also: Ravenswood, Kaine 2015, p. 557, who attach the label of "indirect employer" to the state due to its dominant power within public supply chains (relating to public procurement). Backer (2008) defines "indirect employees" as "employees of an entity hired to produce products or deliver services to another party". 


\section{Transnational corporation as the "indirect employer"}

When formulating the concept of the indirect employer, Pope John Paul II emphasises that the responsibility for shaping the economic and social system should lie mainly with the state, but he notes that in the era of manifold international relationships and links, the power of the state is significantly limited by the so-called multinationales and transnationales. The Pope uses these terms to describe international organisations that control large-scale means of industrial production. These include, i.a. transnational (international, multinational, global) corporations (companies, concerns, holdings).

International capital groups (described, as mentioned before, with many other, synonymous expressions) are defined in various ways. International Labour Organisation uses the term multinational enterprise, understood as enterprises - whether fully or partially state-owned or privately owned - which own or control production, distribution, services or other facilities outside the country in which they are based (ILO 2017, sec. 6). OECD defines multinational businesses as companies or other entities established in more than one country and so linked that they may co-ordinate their operations in various ways (OECD 2011, sec. I.4). The Institute of International Law uses the following definition - multinational enterprise is a group of companies operating under common ownership or control, whose members are incorporated under the laws of more than one state (Institut de Droit International 1995).

It needs to be noted that the above-mentioned definitions, while correct in formal terms, fail to account for what has been explored in detail by political scientists and economic experts. Indeed, scientific publications on transnational corporations consider them as organisations that have a considerable economic capacity and the ability to exert some influence on national governments - characteristics which are not reflected in any of the definitions cited above. It addition, it is obvious that not all organisations that fit the above-mentioned definitions would be of interest to political scientists or the Pope himself.

In order to capture the feature of transnational corporations, which makes it reasonable to include them among the referents of the Pope's notion of indirect employer, it is important to recognise their dual nature. When transnational corporations are considered as indirect employers, it is not because of the fact that they consolidate entities (companies) operating (or at least registered) in more than one country - in this aspect, multinational companies would merely constitute groups of interconnected "direct" employers. It is rather about the fact that corporations operate in a special space that appeared as a consequence of globalisation. This space, in which transnational corporations operate, is a supranational space, that I would like to define as a space where laws established by individual states no longer define boundary conditions for business operations, but are merely a circumstance taken into consideration when choosing the way of business engagement in a particular state (possible options include, among others: export, strategic alliance, licensing, and direct investments). This supranational space is a virtual, imagined space, and to say that transnational corporations operate within 
it means that they have managed (due to the large scale of their operations) to liberate themselves from the restrictions imposed by individual states and to derive maximum benefits from the opportunities afforded by globalisation. It seems that this liberation from state authority made it possible for transnational corporations to take the role of partners in their relations with states, and the role of actors in international relations. As actors, they play a significant role in deciding about the future of the world.

What might be interesting is that the growing strength of transnational corporations and their capacity to exert influence on states had drawn the attention of the Holy See long before 1981. It is important to note that this topic was addressed at length by Pope Pius XI in his Quadragesimo Anno encyclical, published half a century earlier. This twohundred-fifty-sixth successor to St. Peter argued in it that the development of market economy had resulted in the accumulation of power and riches in the hands of the few. Referring to international financial institutions, Pope Pius XI wrote about internationalism of finance, or international imperialism, "whose country is where profit is" (Pius XI 1931, sec. 109). The operations of those powerful institutions (lenders) were, the Pope argued, harmful, because, driven by their desire to maximise profit, they facilitated the development of entities that in the competitive environment "fight the most violently, those who give least heed to their conscience" (Pius XI 1931, sec. 107). In Pope Pius XI's opinion, the emergence of those new powerhouses had significantly hampered the pursuit of the vision of harmonious growth, as described in the Rerum Novarum encyclical, because it reduced the authority of the state, which, according to both Pope Leo XIII and Pope Pius XI, having an important role to play in reconciling the interests of labour and capital, "ought to sit on high like a queen and supreme arbitress" (Pius XI 1931, sec. 109).

Pope Pius XI's postulates, which, in my opinion, inspired the John Paul II's concept of the indirect employer, needed to be somehow updated to account for a series of events that took place in the period between the publication of the Quadragesimo Anno and Laborem Exercens encyclicals. In the years preceding the publication of the encyclical on human work, transnational corporations had risen to power on an unprecedented scale. A famous event that influenced the way corporations came to be perceived in that period was, without doubt, the Chilean coup d'état. In 1973, Salvador Allende, a democratically elected president of Chile, was overthrown by General Augusto Pinochet's junta. Political-science assessments of that event emphasise the important role played by International Telephone \& Telegraph Corporation (ITT), an US company that found itself threatened by the nationalization plans of the new government. That part of Chilean history became a textbook example of the role of non-state actors in international politics.

In addition, the encyclical was likely to be influenced by documents of international organisations, published in the 1970s, on the issue of the international capital groups' power. Such documents include the Tri-partite Declaration of Principles Concerning Multinational Enterprises and Social Policy, adopted by the Administrative Council, International Labour Office, on 16 November 1977, and OECD Guidelines for Multinational 
Enterprises, adopted on 21 June 1976 (OECD 2011). Both those documents were, in fact, a tacit way to ask supranational corporations to act ethically in relation to weak, developing states that were vulnerable to their pressures.

In the early 1980s, John Paul II, aware of the abating authority of the state and the increasing power of large corporations, perceived those developments not as a perversion that could be eliminated, but as a permanent fixture in the new reality. In his concept of the indirect employer, the Pope mentioned limitations faced by countries to voice his conviction that for a nation state there was no coming back to the "sitting on high", and that in the future the state would not be able to enforce high work standards on its own.

Moreover, it is important to note that nowadays supranational corporations have unquestionable power. An important event that marked another increase in the importance of corporations was the ending of the Cold War. In Polish literature on the subject it is argued that, when barriers to trade and globalisation were removed, international institutions started to play more and more prominent roles, while nation states significantly diminished in importance (Biskup 2010, p. 127, 144-145, 147; Lech 2010, p. 223; Oręziak 2012). When major decisions came to be made at the supranational level, international corporations operating at this level gradually gained leverage over those decisions. The study of international relations and political geography concepts now considers transnational corporations not only as the target group of regulations being introduced by countries, but also as actors in international relations (Mielnik 2008 , p. 215ff; Otok 2011, p. 180). Some concepts even go as far as to give them fundamental roles, arguing that transnational corporations are the products of globalisation and its liberal logic, and, at the same time, its creators (Marzęda 2007, p. 10-11). Many scholars seem to believe that the increase in the power of transnational corporations is a challenge to sovereignty, while others advocate that, in this day and age, sovereignty is not only an attribute of states, but also of transnational corporations (Karski 2010, p. 178-183).

As noted by Pope John Paul II, the increase in the importance of international organisations controlling large-scale industrial production is no trifling matter for the relations between work and capital. It is argued that the crisis of labour law that is observed globally can be linked to the declining significance of nation states. Previously, the work-capital balance was based on retaining capital within the borders of a nation state, whose policies were, to a large extent, influenced by employees, or voters. The liberalisation of trade and financial flows has markedly increased the bargaining power of capital. Liberalisation removed local constraints on capital (corporate shift to the above-mentioned supranational space), and, as a result, changed the attitude of states towards it. Under these conditions, employment levels in individual states depend less and less on the internal policy of each state, and more and more on changes in external circumstances, such as international demand, supply, and competition. By making decisions about where to invest, transnational corporations significantly affect the international distribution of labour and the number and quality of jobs created in each state. As a result, states are competing against one another, soliciting investments, and 
creating "a more favourable investment climate", which often means the liberalisation of labour law (Marzęda 2007, p. 115).

Transnational corporations have learned how to exert their newly acquired influence to bend governments to their will and pave way for introducing changes that are favourable to them (Arthurs 2006, p. 55). Put simply, this influence is intended to liberalise, deregulate, privatise, and commercialise government systems (Lech 2010, p. 225).

Joel Bakan's book entitled The Corporation: The Pathological Pursuit of Profit and Power (2005) describes ways the corporations use to affect virtually all aspects of our social and personal lives. Important elements of this influence include lobbying, funding of political parties, and the so-called "revolving-door" mechanism, consisting in creating jobs in the private sector for "deserving" politicians. It is emphasised in literature that the liberalisation of labour law encouraged by transnational corporations may be the result of their ability to have academics working on labour law prepare not so much expert opinions about specific issues, as comprehensive studies, which interpret the law in a way that serves the interests of capital (Oniszczuk 2010, especially p. 332). This might also be the case in the field of economics and other branches of knowledge, and can involve sponsorship of NGOs, scientific conferences, research, etc.

By reference to the term indirect employer, as advocated by the Pope, an interesting observation can be made in relation to the idea known as Corporate Social Responsibility. Transnational corporations, which, especially in developed countries, ostentatiously take care of the environment and offer well-paid jobs associated with a certain prestige and career prospects (Zorska 2007, p. 287-291), tend to lobby for the liberalisation of norms related to environmental protection and labour law (Arthurs 2002, p. 478; Oniszczuk 2010, especially p. 321ff). Transnational corporations, as direct employers, make efforts in the field of CSR, and, at the same time, as indirect employers, take completely opposite actions. In doing so, they sometimes refer to a rather perfidious argument, namely the threat of the compliance culture. It boils down to claiming that when required to comply with mandatory norms, employers will do just what is required and will not be likely to take any further CSR efforts on their own, which they would otherwise take if there were no regulations at all.

There is one more paradox associated with the issue of transnational corporations. Usually, it is suggested that the only possible way of bringing them under control is to encourage closer international cooperation and create supranational laws as in the case of the European Union. ${ }^{2}$ At first glance, this suggestion seems valid and even support-

2 According to Scaperlanda (1998, p. 1767-1768) this solution is supported by John Paul II himself. The author cites in his paper passages from Sollicitudo Rei Socialis, Centesimus Annus and finally Laborem Exercens and generally argues that expansion of multinational enterprises is inevitable and potentially beneficiary to developing countries so that improving investing climate should be a concern of all. By the way, it was noted in the literature that "John Paul's views on economic systems have been construed much differently by various commentators some of whom, it seems, have been seeking approval for their own views in what he says rather than searching for the meaning that John Paul himself intends 
ed by examples of regulations introduced by the EU in relation to groups of companies operating in more than one Member State. What is a cause for concern, however, is the fact that closer international cooperation is usually encouraged by the corporations themselves. International cooperation facilitates standardisation, which releases transnational corporations from the obligation to adapt their structures and policies to local conditions. Moreover, as mentioned earlier on, when power is transferred to the supranational level, this naturally supports such organisations. Indeed, at the supranational level democratic control is weaker (e.g. Anioł 2002, p. 11), and various corporate influences are strengthened. This makes such organisations as the European Union particularly susceptible to being influenced by them. While it is perhaps somewhat exaggerated and generalised a view, closer international cooperation, as a simple remedy for bringing corporations under control, can turn out to be a cure, which, instead of tackling, is likely to further aggravate the problem.

The significant influence exerted by international corporations on social and political systems and labour laws, as described by the Pope, who included corporations in the term "indirect employer", is also important for another reason - it brings forward an issue that is crucial to labour law and which is now being marginalised. This issue is opposition to approaches assuming automatism or determinism in relation to economic and social phenomena, and is rooted in Catholic social teaching (Lower 2007, p. 152-153). By defining the term indirect employer, Pope John Paul II argues that current transformations are orchestrated by specific organisations, including international corporations, that are able to exert political pressure. The lesson that can be learned by legal doctrine from the Laborem Exercens encyclical is that all theories about economic determinism, which cannot be opposed and which affects labour law amendments, should be approached with more reserve. It is more important to focus on the demiurges behind those changes, including international corporations.

\section{Closing remarks}

It seems that the continuous validity of Pope John Paul II's concept was confirmed by Pope Benedict XVI in his Caritas in Veritate encyclical. Pope Benedict XVI argues in it that contemporary states have to face limitations imposed to its sovereignty by the new international economic/trade and financial contexts, which are also characterised by the growing mobility of financial capital and tangible and intangible means of production. The encyclical goes on to emphasise that this new context has affected the political authority of states (Benedict XVI 2009, sec. 24). Pope Benedict XVI opposes, however, any fatalistic attitudes to globalisation. Such attitudes are based on the belief that current processes are the product of "anonymous impersonal forces or structures independent of

to convey" (O’Boyle 2005, p. 521). The article gives no place to expand the topic of John Paul II's perspective on the role of nation and the nation state, but see e.g. John Paul II 2005, p. 29. 
the human will" (Benedict XVI 2009, sec. 42) and are in contradiction to Catholic social teaching, in the light of which any injustice is associated with the original sin, ergo with human volition. Therefore, as written by the Pope, "it is not the instrument [economy, market] that must be called to account, but individuals, their moral conscience and their personal and social responsibility" (Benedict XVI 2009, sec. 36). The Pope also strongly emphasises that contempt for the human ability to control developmental distortions is seriously wrong (Benedict XVI 2009, sec. 14) and argues that:

[...] development will never be fully guaranteed through automatic or impersonal forces, whether they derive from the market or from international politics. Development is impossible without upright men and women, without financiers and politicians whose consciences are finely attuned to the requirements of the common good (Benedict XVI 2009, sec. 71).

When the term indirect employer is considered, e.g. in the context of Pope Benedict XVI's teaching, it is evident that Pope John Paul II made no mistake by developing it on the basis of various ontological meanings. This way the Pope showed that the responsibility for the existing state of affairs always rests with people. People are also the ones who manage international corporations, whose influence on working conditions is in the present times much more profound than the one which seems apparent when these corporations are considered as employers in the classical meaning of the term.

\section{References}

Anioł W. (2002) Deficyt demokratyczny w systemie globalnym, "Studia Europejskie", nr 4. Arthurs H.W. (2002) Private Ordering and Workers' Rights in the Global Economy: Corporate Codes of Conduct as a Regime of Labour Market Regulation [in:] J. Conaghan, R.M. Fischl, K. Klare (eds), Labour Law in an Era of Globalization. Transformative Practices and Possibilities, Oxford-New York.

Arthurs H.W. (2006) Who's Afraid of Globalization? Reflections on the Future of Labour Law [in:] J.D.R. Craig, S. Michael Lynk (eds.), Globalization and the Future of Labour Law, Cambridge. Backer L.C. (2008) From Moral Obligation to International Law: Disclosure Systems, Markets and the Regulation of Multinational Corporations, "Georgetown Journal of International Law", vol. 39, issue 4.

Bakan J. (2005) The Corporation: The Pathological Pursuit of Profit and Power, New York. Benedict XVI (2009) Caritas in veritate, http://w2.vatican.va/content/benedict-xvi/en/encyclicals/ documents/hf_ben-xvi_enc_20090629_caritas-in-veritate.html (access: 19 August 2019). Biskup P. (2010) Korporacje transnarodowe a wspótczesne formy państwa i suwerenności [in:]

J. Menkes, T. Gardocka (red.), Korporacje transnarodowe. Jeden temat, różne spojrzenia, Warszawa.

Davidov G. (2015) Indirect Employment: Should Lead Companies be Liable?, "Comparative Labor Law \& Policy Journal", vol. 37. 
Garcia R.A. (2016) Modern Accountability for a Modern Workplace: Reevaluating the National Labor Relations Board's Joint Employer Standard, “The George Washington Law Review", vol. 84 .

ILO (2017) Tripartite Declaration of Principles Concerning Multinational Enterprises and Social Policy, $5^{\text {th }}$ Edition, http://www.ilo.org/wcmsp5/groups/public/---ed_emp/---emp_ent/--multi/documents/publication/wcms_094386.pdf (access: 19 August 2019).

Institut de Droit International (1995) Obligations of Multinational Enterprises and their Member Companies, http://www.idi-iil.org/app/uploads/2017/06/1995_lis_04_en.pdf (access: 19 August 2019).

John Paul II (1981) Laborem Exercens, https://w2.vatican.va/content/john-paul-ii/en/encyclicals/ documents/hf_jp-ii_enc_14091981_laborem-exercens.html (access: 19 August 2019).

John Paul II (1987) Sollicitudo rei socialis, http://w2.vatican.va/content/john-paul-ii/en/encyclicals/ documents/hf_jp-ii_enc_30121987_sollicitudo-rei-socialis.html (access: 19 August 2019).

John Paul II (1991) Centessimus annus, https://w2.vatican.va/content/john-paul-ii/en/encyclicals/ documents/hf_jp-ii_enc_01051991_centesimus-annus.html (access: 19 August 2019).

John Paul II (2005) Pamięć i tożsamość. Rozmowy na przełomie tysiacleci, http://zwola-old. karmelicibosi.pl/p/z/formacja/pamitozs.pdf (access: 19 August 2019).

Johnson M. (2005) Indirect Employer Liability: The Ninth Circuit Limits Liability for Racial Discrimination, "U.C. Davis Law Review”, vol. 38, issue 2.

Karski K. (2010) Zakres podmiotowości korporacji transnarodowej w prawie międzynarodowym [in:] J. Menkes, T. Gardocka (red.), Korporacje transnarodowe. Jeden temat, różne spojrzenia, Warszawa.

Kelley F. (1908) The Responsibility of the Consumer, "The Annals of the American Academy of Political and Social Science", vol. 32.

Lech M. (2010) Zdolność oddziaływania korporacji transnarodowych na współczesne stosunki międzynarodowe w dobie procesu globalizacji [in:] J. Menkes, T. Gardocka (red.), Korporacje transnarodowe. Jeden temat, różne spojrzenia, Warszawa.

Lower M. (2007) John Paul II and Employee Participation in Corporate Governance, "Notre Dame Journal of Law, Ethics \& Public Policy”, vol. 21.

Marzęda K. (2007) Proces globalizacji korporacyjnej, Bydgoszcz.

McMorran Sulentic A. (2006) Human Dignity First: John Paul II, Systems Analysis and The ERISA Fiduciary, "Journal of Catholic Legal Studies", vol. 45.

Mielnik B. (2008) Kształtowanie się pozapaństwowej podmiotowości w prawie międzynarodowym, Wrocław.

O’Boyle E.J. (2005) John Paul II's Vision of the Social Economy, "International Journal of Social Economics", vol. 32, issue 6.

OECD (2011) OECD Guidelines for Multinational Enterprises, http://www.oecd.org/daf/inv/ mne/48004323.pdf (access: 19 August 2019).

Oniszczuk J. (2010) Prawo pracy a korporacje transnarodowe [in:] J. Menkes, T. Gardocka (red.), Korporacje transnarodowe. Jeden temat, różne spojrzenia, Warszawa.

Oręziak L. (2012) OFE w Polsce - produkt ekspansji globalnych instytucji finansowych, "Polityka Społeczna”, nr 11/12. 
Otok S. (2011) Geografia polityczna. Geopolityka - ekopolityka - globalistyka, Warszawa.

Pius XI (1931) Quadragesimo anno, http://w2.vatican.va/content/pius-xi/en/encyclicals/documents/hf_p-xi_enc_19310515_quadragesimo-anno.html (access: 19 August 2019).

Ravenswood K., Kaine S. (2015) The Role of Government in Influencing Labour Conditions through the Procurement of Services: Some Political Challenges, "Journal of Industrial Relations", vol. 57, issue 4.

Sanetra W. (1989) Pracownicy i pracodawcy - niektóre podstawowe problemy, pojęcia i konstrukcje [in:] W. Sanetra (red.), Pracownicy i pracodawcy: materiały XVI Zimowej Szkoły Prawa Pracy, Karpacz, marzec 1989, Wrocław.

Scaperlanda A. (1998) John Paul II's Vision of the Role of Multinational Enterprise Expansion in Building the Social Economy, "International Journal of Social Economics", vol. 25, issue 11/12. Wagner B. (1990) W sprawie „pracodawcy pośredniego", "Państwo i Prawo”, nr 10.

Williams G.H. (1982) John Paul II's Concepts of Church, State, and Society, "Journal of Church and State", vol. 24, issue 3.

Wratny J. (1994) Conflict and Co-Operation in the Labour - Management Relations Comparative Legal Approach: Canada-Poland, "Revue generale de droit”, vol. 25.

Zieliński T. (1986) Prawo pracy. Zarys systemu. Część I ogólna, Warszawa.

Zorska A. (2007) Korporacje transnarodowe. Przemiany, oddziaływania, wyzwania, Warszawa. 
